- c нормами финансового права - осуществление туристской деятельности, как и любой коммерческой деятельности, носит рисковый характер. За несколько последних лет туристская индустрия пережила ряд финансовых проблем, вызванных банкротством туристских компаний. Вопросы финансового обеспечения туристской деятельности занимают важное место в структуре законодательства о туризме, в частности при определении порядка формирования, резервного фонда денежных средств объединения туроператоров в сфере выездного туризма, предназначенного для финансирования деятельности по оказанию экстренной помощи туристам.

Таким образом, можно сделать вывод, что туристские правоотношения регулируются не только законодательством о туризме, но и положениями других нормативно-правовых актов, как в, частноправовой, так и в публично-правовой сфере.

$$
* * *
$$

1. Федеральный закон от 24 ноября 1996 г. № 132-Ф3 (в ред. от 28 декабря 2016 г.) «Об основах туристской деятельности в Российской Федерации» // Собрание законодательства РФ. - 1996. - № 49. - Ст. 5491.

2. Указ Президента РФ от 15 марта 2000 г. № 511 (в ред. от 28 июня 2005 г.) «О классификаторе правовых актов» // Собрание законодательства РФ. - 2000. - № 12. - Ст. 1260.

3. Керимов Д.А. Методология права: Предмет, функции, проблемы философии права. - 6-е изд. - М.: Изд-во СГУ, 2011. - 521 с.

4. Кусков А.С., Сирик Н.В. Правовое обеспечение сферы туризма: учебное пособие / А.С. Кусков, Н.В. Сирик. - М.: ФОРУМ; ИНФРА-М, 2014. - 400 с.

5. Правоведение: учебник / отв. ред. В.Д. Перевалов. - М.: Норма: Инфра-М, 2013. - 576 с.

6. Правовое обеспечение туризма: учебник / коллектив авторов: под общ. ред. Е.Л. Писаревского. - М.: Федеральное агентство по туризму, 2014. - 336 с.

7. Юридическая техника: словарь-справочник / под ред. А.В. Малько. - 2-е изд., перераб. и доп. Москва: Проспект, 2017. - 248 с.

\title{
Федечко Ф.И. \\ О некоторых особенностях правового регулирования жилого помещения как объекта гражданского права дореволюционной России
}

\author{
Ульяновский государственный университет
} (Россия, Ульяновск)

doi:10.18411/spc-20-11-2017-17

idsp: 000001:spc-20-11-2017-17

\section{Аннотация}

В данной статье рассматриваются различные подходы к изучению и определению правового регулирования оборота жилых помещений как объекта гражданского права дореволюционной России. Приведены исторические и правовые аспекты становления и развития российского законодательства, регулирующего владение и пользование жилыми помещениями. Данные отношения рассматриваются в рамках гражданского законодательства Российской Империи.

Ключевые слова: жилое помещение, объект гражданского права, договор, наймодатель, дореволюционное законодательство.

\section{Abstract}

This article examines various approaches to the study and definition of legal regulation of the turnover of residential premises as an object of civil law in pre-revolutionary Russia. Historical and legal aspects of the formation and development of Russian legislation regulating the possession and use of living quarters are given. These relations are considered in the civil law of the Russian Empire.

Keywords : residential building, object of civil law, contract, landlord, prerevolutionary legislation. 
Так, в дореволюционной России правовое регулирование отношений связанных с оборотом жилых помещений осуществлялось исключительно в рамках гражданского законодательства. Такие нормы содержались в одной из глав Свода законов гражданских (том X Свода законов Российской Империи) [1], которая называлась «О найме и отдаче в содержание частных имуществ». Необходимо отметить, что данные отношения по передаче в пользование жилого помещения оформлялись договором имущественного найма.

Вместе с тем норм, специально посвященных отношениям найма жилых помещений, в законодательстве Российской Империи не было. Лишь в ст. 1702 и 1707 Свода законов гражданских упоминается о найме городских строений и домов, однако детально порядок и схема регулирования таких отношений разработана и закреплена не была.

До революции 1917 г. потребность большей части населения в жилье в городах в основном удовлетворялась путем найма жилых помещений, что, однако, не отражалось на степени законодательного регулирования указанных отношений. При этом, действовавшие в дореволюционный период нормы Свода законов гражданских во многом не соответствовали экономическим и общественным отношениям своего времени.

Так, К.П. Победоносцев отмечал, что «русский закон крайне скуден общими определениями о найме, и те, которые есть в нем, имеют вид случайный и отрывочный», что являлось причиной «затруднений в разрешении юридических вопросов, из найма возникающих» [2]. Высказывалось мнение о необходимости совершенствования законодательства о найме имущества [3].

Так, в Своде законов гражданских отсутствовало определение договора имущественного найма, вместе с термином «найм» в законодательстве использовались термины «аренда», «снятие», которые обозначали имущественный найм и не имели иного самостоятельного юридического содержания.

Г.Ф. Шершеневич имущественным наймом называл договор, в силу которого одна сторона за определенное вознаграждение обязывается предоставить другой стороне временное пользование своей вещью [4]. Такое понимание сущности договора имущественного найма соответствовало ст. 1691 Свода законов гражданских, в которой были указаны обязательные условия договора имущественного найма предмет, срок и цена.

Таким образом, отличительными чертами договора имущественного найма, урегулированного Сводом законов гражданских, можно назвать осуществление передачи определенного имущества во владение и пользование, а также срочность и возмездность такой передачи.

Кроме того, понятие «жилое помещение» в дореволюционном законодательстве не использовалось. При этом для обозначения жилого помещения или жилого дома, являвшихся предметом договора имущественного найма, в законодательстве употреблялись такие понятия, как «частные имущества», «строения», «городские строения», «дома».

В юридической литературе рассматриваемого периода [5] можно также встретить такие термины, обозначающие жилые дома и помещения, как «недвижимые имущества в городах», «домовладения», и часто использовался термин «помещения», «квартиры», «комнаты». Наряду с квартирами и комнатами, сдаваемыми в наем, в юридической литературе и судебной практике в качестве предмета найма назывались «углы и койки». Причем в этом случае речь шла о найме неизолированной части комнаты, где можно было переночевать.

Также необходимо отметить, что законодательство Российской Империи не содержало специальных требований к помещениям, которые могли использоваться для проживания. 
В законодательстве Российской Империи первоначально был установлен общий предельный срок найма недвижимого имущества - 12 лет (с некоторыми исключениями для отдельных местностей Российской Империи и для найма земли). Однако такой короткий предельный срок найма не был выгоден для лиц, осуществлявших значительные капиталовложения в нанимаемую недвижимость. С учетом этого в 1911 г. общий предельный срок имущественного найма был увеличен до 36 лет.

В рассматриваемый период размер платы за наем жилья определялся исключительно по соглашению сторон договора. В период 1916-1917 гг. нормативными правовыми актами Правительства наймодателям было запрещено повышать цены на жилые помещения. [6].

На смену Свода законов гражданских готовилось Гражданское уложение Российской Империи, разработка которого велась более десяти лет. В конце XIX в. был опубликован проект книги V Гражданского уложения - «Об обязательствах», а также комментарии к ней [7]. В 1915 г. указанный проект после доработки был внесен в Государственную Думу, однако из-за событий Первой мировой войны он не был принят в качестве закона, так и оставшись на уровне законопроекта [8].

$$
\text { *** }
$$

1. Кодификация российского гражданского права. Ектеринбург,2003.

2. Победоносцев К.П. Курс гражданского права. Т. 3. (По изданию 1896 г.). М., 2003. 350 с.

3. Кавелин К.Д. Собрание сочинений. Т. 4. СПб., 1898. 710 с.

4. Шершеневич Г.Ф. Учебник русского гражданского права. М., 1995. 358 с.

5. Законы гражданские с разъяснениями Правительствующего Сената и комментариями русских юристов. Кн. 3. (Составитель Тютрюмов И.М.). (По изд. 1911 г.). М., 2004.

6. Постановления от 27 августа 1916 г. и от 5 августа 1917 г. (Аскна-зий С.П. Советское жилищное право. М., 1940. С. 18; Законы гражданские с разъяснениями Правительствующего сената и комментариями русских юристов. Кн. 3. (Составитель Тютрюмов И.М.). (По изданию 1911 г.). М.,

7. Гражданское уложение. Проект утвержденной Редакционной комиссии по составлению Гражданского уложения. Книга пятая. Обязательства. С объяснениями. СПб., 1899.

8. Тиле А.А. Проект Гражданского уложения России 1905-1913 гг. (Общая характеристика). М., 1984.

\section{Федорова А.С. \\ Прокурорский надзор за соблюдением законности в оперативно-розыскной деятельности: проблемные аспекты}

Санкт-Петербургский юридический институт (филиал) федерального государственного казенного образовательного учреждения высшего образования «Академия Генеральной прокуратуры Российской Федераџии»

doi:10.18411/spc-20-11-2017-18

(Россия, Санкт-Петербург)

idsp: 000001:spc-20-11-2017-18

Оперативно-розыскная деятельность с древних времён характеризуется как особый вид правоохранительной деятельности государства, направленный на противодействие преступности и обеспечение безопасности посредством применения полицейскими органами специфических способов, основанных на гласных и негласных средствах и методах получения информации. Безусловно, большинство из таких средств и методов затрагивают и в какой-то степени ограничивают права и свободы граждан, закреплённые в Конституции РФ, однако без их использования бороться с преступными проявлениями на практики весьма сложно.

Впервые организационные и правовые основы данного вида правоохранительной деятельности государства на законодательном уровне были закреплены 13 марта 1992 года, с принятием Закона Российской Федерации "Об оперативно-розыскной деятельности в Российской Федерации". При этом сегодня 